\title{
Pensononowoor
}

2021, vol. 86, 39-55

https://doi.org/10.12657/denbio.086.005

\author{
Hoang Van Sam*, Do Quang Tung, Anna K. Jasińska, François Rion, \\ Phung Thi Tuyen, Duong Thi Bich Ngoc, Do Thanh Tam, \\ Sébastien Bétrisey, Yi-Gang Song, Gregor Kozlowski
}

\section{Diversity, distribution, and threats of the Juglandaceae in Vietnam}

Received: 10 April 2021; Accepted: 15 September 2021

\begin{abstract}
Vietnam is one of the main centers of generic diversity for Juglandaceae worldwide. In this study, we present for the first time a province-wide distribution of all 3 subfamilies, 7 genera, and 11 Vietnamese species, and give an update on the habitats of all Vietnamese Juglandaceae species, their uses, and current threats. Juglandaceae are found throughout Vietnam. However, most species occur predominantly in the northern part of the country between 600 and $1200 \mathrm{~m}$. Some taxa range is found extensively from sea level up to 2,500 meters above sea level. According to the IUCN Red List, Rhoiptelea chiliantha, Carya sinensis, and Pterocarya tonkinensis are threatened while Engelhardia spicata, E. serrata, Alfaropsis roxburghiana, Pterocarya stenoptera are classified as least concerned (Carya tonkinensis is threatened locally, and Engelhardia spicata var. colebrookiana and Platycarya strobilacea merit "threatened" designation in Vietnam's Red Data Book. The most frequent threats are logging, land-use change, and habitat destruction due to artificial wood plantations or road construction. Until now, no conservation measures have been applied for any of the species in Vietnam, although some species occur in national parks.

Our study gives an important update on the current diversity and distribution of Juglandaceae in Vietnam. We point out the need for a correct assessment of the threat status of various species on a national and international scale to protect the rarest and most endangered of them. Further research, the use of various forms of protection of individual taxa and/or their habitats, and drawing the attention of an international group of researchers to the urgent need to work together to protect biodiversity in Vietnam hot spots are necessary.
\end{abstract}

Keywords: Conservation biology, relict trees, Rhoiptelea, Engelhardia, Alfaropsis

Addresses: H.V. Sam, P.T. Tuyen, D.T.B. Ngoc, D.T. Tam, Vietnam National University of Forestry, QL21, TT. Xuân Mai, Chương Mỹ, Hanoi, Vietnam, e-mails: samhv@vnuf.edu.vn, tuyenpt@vnuf.edu.vn, tuyenpt@vnuf.edu.vn, dothanhtam1997@gmail.com; (1) HVS https://orcid.org/0000-0001-7266-439X D.Q. Tung, Management board for forestry projects, Ministry of Agriculture and Rural development, No 2 Ngoc Ha Street, Ba Dinh, Hanoi, Vietnam; Sustainable Forest Management Research Institute, University of Valladolid, 34004 Palencia, Spain, e-mail: tung.kl@mard.gov.vn

A.K. Jasińska, Institute of Dendrology, Polish Academy of Sciences, Parkowa 5, PL-62-035 Kornik, e-mail: ajasinska@man.poznan.pl; (1) https://orcid.org/ 0000-0003-4661-027X

F. Rion, S. Bétrisey, Department of Biology and Botanic Garden, University of Fribourg, Chemin du Musée

10, CH-1700 Fribourg, Switzerland, e-mails: francois.rion@friphila.ch, sebastien.betrisey@unifr.ch

G. Kozlovsky, Department of Biology and Botanic Garden, University of Fribourg, Chemin du Musée 10,

CH-1700 Fribourg, Switzerland, Natural History Museum Fribourg, Chemin du Musée 6,

CH-1700 Fribourg, Switzerland, e-mail: gregor.kozlowski@unifr.ch;

(D) https://orcid.org/0000-0003-4856-2005

Y.-G. Song, Shanghai Chenshan Plant Science Research Center, Chinese Academy of Sciences,

Chenhua Road No.3888,Songjiang, Shanghai 201602, China, e-mail: cherish-faith@163.com,

(1) https://orcid.org/0000-0003-2584-2338

*corresponding author 


\section{Introduction}

The Juglandaceae are one of the most emblematic angiosperm families composed entirely of woody species (Simpson, 2010). Additionally, since all its members are relict trees, the Walnut family has a high scientific and conservation value (Schaarschmidt, 2014; Kozlowski, Bétrisey \& Song 2018). Attempts to explain the vague phylogenetic relationships, taxonomy, and biogeography of the Juglandaceae have been and are still being undertaken by successive researchers (e.g. Manning, 1978; Manchester, 1987; Manos \& Stone, 2001; Manos et al., 2007; Mu et al., 2020; Song et al., 2020a, b), but still requires further research, especially within the Juglandoideae subfamily, where the phylogenetic relationships of the six genera are still uncertain. The family, including the monotypic genus Rhoiptelea, is monophyletic and comprises ten extant genera and approximately sixty species of trees (Manos \& Steele, 1997; Stone, 1993) mostly distributed throughout mid and low latitudes of the Northern Hemisphere.

Southeast Asia is a global biodiversity hotspot in terms of both plant and animal species (Song et al., 2020a; Šlechtová et al., 2021). Vietnam makes a significant contribution to this biodiversity, despite a history of massive forest damage during the Vietnam War, a large number of highly endangered terrestrial and freshwater ecosystems, and a still unclear conservation policy (MOF, 1991; Department of Forest Protection, 1997; Mercker \& Vu, 1997). Vietnam, as one of the plant biodiversity centers (Hoang, Baas \& Ke ler, 2008; Hoang et al., 2011), is considered the second (after China) geographic region of generic diversity of Juglandaceae (Kozlowski, Bétrisey \& Song, 2018). The main differences in the number of genera

Table 1. Herbarium specimens examined. Abbreviations: Vietnam Forestry Herbarium (VNF), Vietnam Academy of Science and Technology (HN), Institute of Tropical Biology Vietnam (VNM), VNU University of Science, Hanoi (HNU), Cuc Phuong National Park Vietnam (CPNP), Forest Inventory and Planning Institute Vietnam (VFM), the National Museum of Natural History of Paris (P)

\begin{tabular}{|c|c|}
\hline Taxon & Specimens examined \\
\hline Rhoiptelea chiliantha & NV Ly 005, 007, 008, 009, Thanh SP 26, Thanh SP27 (VNF) \\
\hline Engelhardia spicata var. spicata & $\begin{array}{l}\text { Anonymous } 17441 \text { (HN); Averyanov L \& NQ Binh } 4534 \text { (HN); Averyanov L et al. } 780 \text { (HN); } \\
\text { DK Harde et.al 63, } 6013 \text { (HN); DH Lien } 1760 \text { (HN); L Pierre 3304 (VNM); LV Thuan 75, 387, } \\
10387 \text { (VFM); NN Chinh } 4327 \text { (VFM); NQ Binh \& DD Cuong 185, } 2274 \text { (HN); NT Hiep et al. } \\
9286 \text { (HN); NV Lien } 91399 \text { (VFM); PV Dung } 1567 \text { (VNF); Petelot } 7641 \text { (VNM); Poilane 1717, } \\
24697 \text { (HN), 5766, } 13631 \text { (VNM); TD Dai } 1204 \text { (HN); TN Ninh } 764 \text { (HN); Thorel } 5289 \text { (VNM); } \\
\text { VV Dung \& NN Chinh } 4325 \text { (VFM); VV Dung } 4324 \text { (VFM); Vidal } 890 \text { (VNM), HV Sam 234, } \\
235 \text { (VNF) }\end{array}$ \\
\hline Engelhardia spicata var. colebrookiana & $\begin{array}{l}\text { DH Lien } 1760(\mathrm{HN}) \text {; LV Thuan } 75 \text { (VFM); Petelot } 7641 \text { (VNM); Poilane 5766, } 13631 \text { (VNM); } \\
\text { Vidal } 890 \text { (VNM), Thanh 156, 290, 291, } 292 \text { (VNF) }\end{array}$ \\
\hline Engelhardia serrata & $\begin{array}{l}\text { DK Harde et.al } 330 \text { (HN); L Pierre } 3301 \text { (VNM); Poilane 13631, } 33361 \text { (VNM); Thorel } 2807 \\
\text { (VNM); W. E Manning } 5837 \text { (HN) }\end{array}$ \\
\hline Alfaropsis roxburghiana & $\begin{array}{l}\text { Anonymous 76, 635; 5326,30113; 32309; 37957; 38016, } 38403 \text { (HN); Averyanov L et al. 147, } \\
\text { 2037, } 2296 \text { (HN); DD Soejarto et al. } 9764 \text { (HN); DT Phieu } 960 \text { (VNF); DT Thinh } 89 \text { (VFM); DE } \\
\text { Atha et al. 5803-96 (HN); LV Luan } 1367 \text { (VNF); LV Thuan } 5929 \text { (VFM); NV Lien } 6524 \text { (VFM); } \\
\text { NV Thanh } 963 \text { (VNF); PD Linh 1414 (VNF), NV Ly 003, PH 43, PH44, PH45 (VNF); PK Loc et } \\
\text { al. } 019489 \text { (HNU); PN Dung 8A, 8B, 20A (VNM);P Thao 704 (VFM); Petelot 5961, 8204, } 8836 \\
\text { (VNM); Poilane 4289; 25770, 26982 (HN), 21A, 60, 4289, 5925, 7888, 8018, 12164, 13110, } \\
\text { 15722 (VNM); TN Ninh \& Dumontet V 5727 (HN);VV Can } 60 \text { (VFM); WE Manning } 21786 \\
\text { (HN); }\end{array}$ \\
\hline Carya sinensis & NH Hien 289 (HN), Duong CP 01, CP 02 (VNF); HV Sam 55, 56, 59, BE 25, BE 26 (VNF) \\
\hline Carya tonkinensis & Petelot 7636 (VNM); VL Thao 5924 (VFM); Thanh PL25, PL26 (VNF) \\
\hline Carya poilanei & Poilane $26964(\mathrm{P})$ \\
\hline Platycarya strobilacea & $\begin{array}{l}\text { Anonymous } 366 \text { (VFM); Averyanov L \& NT Hiep } 4916 \text { (HN); Averyanov L et al. 794, 1633, } \\
\text { 4918, } 5618 \text { (HN); DK Harde et.al 018508, 018509, } 018510 \text {, 018511, } 018512 \text { (HNU); DE Atha } \\
\text { et al. } 4851 \text { (HN); NT Hiep et al. 364, } 659 \text { (HN); NH Cuong \& LV Ly } 1458 \text { (VNF); NN Thin } \\
\text { 022258, 022262, 022309, 022310, 022351 (HNU); PK Loc et al. 462, 1280, } 4618 \text { (HN); PV } \\
\text { Dung } 1520 \text { (VNF); Petelot } 8218 \text { (VNM); HV Sam 56, 57, Thanh PL57, PL58 (VNF) }\end{array}$ \\
\hline Pterocarya tonkinensis & $\begin{array}{l}\text { A Chevalier } 37538 \text { (VNM); Anonymous } 3039 \text { (HN); Averyanov L et al. } 1182 \text { (HN); Cadays } \\
38266 \text { (VNM); D Thuan 7, } 2929 \text { (VFM); LV Thuan } 387 \text { (VFM); NA Tiep } 064 \text { (VFM); NN Chinh } \\
4326 \text { (VFM); PN Dung } 18 \text { (VNM); Petelot 7632 (VNM); Poilane } 33029 \text { (VNM); VV Dung \& } \\
\text { NN Chinh 4323 (VFM); NV Ly 001, 038, 039, 040, PH 30, PH31 (VNF);HV Sam 001HB, 002, } \\
\text { 003MC, 025, } 026 \text { (VNF); Thanh 235, } 236 \text { (VNF). }\end{array}$ \\
\hline Pterocarya stenoptera & $\begin{array}{l}\text { A Gramain } 602 \text { (HN); Anonymous } 37538 \text { (HN); Averyanov L \& NQ Binh } 3841 \text { (HN); Averyanov } \\
\text { L \& NT Hiep } 3931 \text { (HN); Averyanov L et al. } 11236 \text { (HN); NN.Thin 022388, } 022555,022570 \\
\text { (HNU); NQ. Binh \& DD Cuong 1104 (HN); NT Hiep et al. } 222 \text { (HN); Poilane 1691, 25629, } \\
25630 \text { (HN); Thanh PL13, PL14, PL15, PL16, PL17 (VNF). }\end{array}$ \\
\hline Juglans regia & NV Ly 189, 190; HV Sam 235, 236 (VNF) \\
\hline
\end{tabular}


in Vietnam are recognition of Alfaropsis, the sinking of Annamocarya within Carya, and treatment of Rhoiptelea (Rhoipteleaceae) with Juglandaceae (Wu \& Raven, 1999; Pham, 2003; Tran \& Nguyen, 1993). Kozlowski et al. (2018) report ten species representing six genera, while in the most current publications the taxonomy has been neglected and the main focus is on genomic research (Guo et al., 2020).

This study aims to deliver the updated synthesis to determine the diversity, distribution, ecology, uses, and conservation status of the Juglandaceae in Vietnam.

\section{Materials and methods}

The current nomenclature in the context of distributional data were studied. The taxonomical description was taken after Chan \& Huyen (2000), Dung (1996) Hô (1992, 2003), modified and checked with the use of specimens from nature and herbaria in Vietnam: Vietnam Forestry Herbarium (VNF), Vietnam Academy of Science and Technology (HN), Institute of Tropical Biology Vietnam (VNM), VNU University of Science, Hanoi (HNU), Cuc Phuong National Park Vietnam (CPNP), Forest Inventory and Planning Institute Vietnam (VFM). Specimens from the National Museum of Natural History of Paris (P) also were checked online (https://www.mnhn.fr/en). The summary of examined specimens is given in Table 1. To confirm herbarium specimens and assess the current situation in Vietnam, field surveys were carried out in 20 provinces in which herbarium records of Juglandaceae were found. During the field surveys, the morphological, ecological characteristics, location, and probable threats of Juglandaceae species were recorded (Nguyen, 2007). Moreover, the use of the different species and their value were determined by interviewing local people and traditional doctors. A total of 60 local people and 15 traditional doctors were interviewed in the research areas.

To evaluate the conservation status of the species we used the IUCN Red List (http://www.iucnredlist. org) and the Vietnam Red Data Book (Ban, 2007). The conservation status of Juglandaceae species in Vietnam was triple-checked by botany experts, management officers, and local people. Distribution maps were created using ArcMap 10.4.1. and QGis 3.10.11.

According to the latest phylogenic studies, there are three Juglandaceae subfamilies: (1) Engelhardioideae including Alfaropsis, Engelhardia, Oreomunnea, and Alfaroa; (2) Juglandoideae including Carya, Cyclocarya, Platycarya, Pterocarya, and Juglans; and (3) Rhoipteleoideae including only one species Rhoiptelea chiliantha (Kozlowski, Bétrisey \& Song, 2018; Manos \& Stone, 2001; Manos et al., 2007; APG III, 2009; APG IV, 2016).

\section{Results}

\section{Engelhardioideae Iljinsk.}

\section{Alfaropsis Iljinsk.}

Alfaropsis roxburghiana (Lindl. ex Wall.) Iljinsk., Bot. Zhurn. (Moscow \& Leningrad) 78(10): 81 (1993). Engelhardia roxburghiana Wall., Pl. Asiat. Rar. (Wallich). 2: 85 (-86; t. 199) (1831). Engelhardia chrysolepis Hance., Ann. Sci. Nat., Bot. sér. 4, 15: 227 (1861). Juglans pterococca Roxb., Hort. Bengal. 68; Fl. Ind. iii. 631. Engelhardia wallichiana Lindl., Numer. List [Wallich] n. 4942. Engelhardia polystachya Radlk., Sitzungsber. Math.-Phys. Cl. Königl. Bayer. Akad. Wiss. München viii. (1878) 385. Engelhardia formosana Hayata., Icon. Pl. Formosan. 6: 61 (1916).

Tree 20-25 m tall, trunk $40-50 \mathrm{~cm}$ in diameter. Young twigs hairy-red or glabrous, covered with orange-skinned glands; blackish adult twigs, with spaced lenticels. Leaves pari- or imparipinnate, leathery, persistent; Rachis of 10-25 cm (including the petiole). Leaflets $2-5$ pairs, subopposite, rarely lower than $5.7-2.6 \mathrm{~cm}$, asymmetrical at the base (more developed acroscopic side, inserted above), acute or obtuse at the apex, margin often revolute, glabrous on the two faces except sometimes on the midrib underneath, the very young hairy-red leaves, with a glandulous lower surface; secondary veins 7-16 pairs, prominent below; petioles of $0.5-1 \mathrm{~cm}$. Inflorescence terminal, often bisexual, in panicles of catkins 5-6 cm, reddish red. Male flowers dense, sessile or short pedicellate; bract and glandular bracts forming 3 teeth; sepals 4 , on a short receptacle, dorsally glandular; stamens 4-8; anther glabrous. Female flowers pedicellate, bracts partly enclosed at the base of the ovary. Ovary globose, stigma 4-lobed. Infructescence $15-25 \mathrm{~cm}$, with tomentose rachis, scaly, winged fruit, pedicellate; wing 3-lobed glandular, terminal lobe $2-6.5 \times 0.6-1.6 \mathrm{~cm}$, the lateral half shorter. Fruits a globose nut, bracts developed into wings, enclosing the base of the fruit, dark brown, with yellowish brown scales, the middle wings $2.5-4 \mathrm{~cm}$ long.

Distribution - Pakistan, Bangladesh, India, SouthEastern China, Taiwan, Cambodia, Indonesia, Laos, Myanmar, Thailand, and Vietnam. This species is distributed in Bac Giang, Bac Kan, Cao Bang, Dong Nai, Gia Lai, Ha Giang, Ha Tinh, Khanh Hoa, Kon Tum, Lam Dong, Lang Son, Lao Cai, Ninh Thuan, Thai Nguyen, Thanh Hoa, Nghe An, Phu Tho, Quang Ninh, Vinh Phuc and Hoa Binh provinces (Fig. 1).

Habitat and Ecology - On shrubby hills, in secondary forests, or regenerating forests on clay- sandy, deep soil. In northern Vietnam it is found in hu- 
mid forests up to $2000 \mathrm{~m}$ a.s.1., in the south, in humid forests or pine forests, on basalt plateaus, between 700 and $1000 \mathrm{~m}$ a.s.l. Natural regeneration is good under the canopy of secondary forests and mixed tree-bamboo forests. Coppice regeneration is very strong. Usually mixed with Ixonanthes cochinchinenesis Pierre (Ixonanthaceae), Symplocos cochinchinensis (Lour.) S.Moore (Symplocaceae), Lithocarpus corneus (Lour.) Rehder (Fagaceae), Pygeum arboretum Endl. (Rosaceae), and Endospermum sinensis Benth (Euphorbiaceae).

Flowering - April to May.

Fruiting - October to November.

Uses - Woody pinkish grey, sapwood, and heartwood indistinct, fine-grained, density 0.30-0.66. Resistant to termites and rot. Used for construction and general furniture and carving. Leaves and bark are poisonous and can be used as a fish poison. Thanks to its thick bark, the species is used to build a green belt to prevent forest fires.
Vernacular names - Chẹo tía, Chẹo trắng.

Engelhardia Lesch. ex Blume.

Engelhardia spicata Lechen ex Blume var. spicata, Bijdr. Fl. Ned. Ind. 10: 528. Engelhardia pterococca (Roxb.) Kuntze, Revis. Gen. Pl. 2: 637 (1891). Engelhardia philippinensis C.D.C., Ann. Sci. Nat., Bot. ser. 4, 18: 35 (1862).

A medium-sized tree, 10-18 (-40) m high. Bark grey, slightly fissured. Inner bark reddish-brown with fibers forming many layers, $6 \mathrm{~mm}$ thick. Young twigs reddish and pubescent, becoming glabrous later, with many rounded lenticels fairly close together. Leaves big, pari- or imparipinnate; rachis 15-30 cm (petioles including); leaflets (3-) 5 (-7) pairs, caducous or persistent, opposite or subopposite, ovate to elliptic, the upper leaflets 11.5-22 × 4.5-8 cm, the lower leaflets smaller, asymmetric at the base, shortly acuminate at the top, margin entire, leathery, glabrous on both

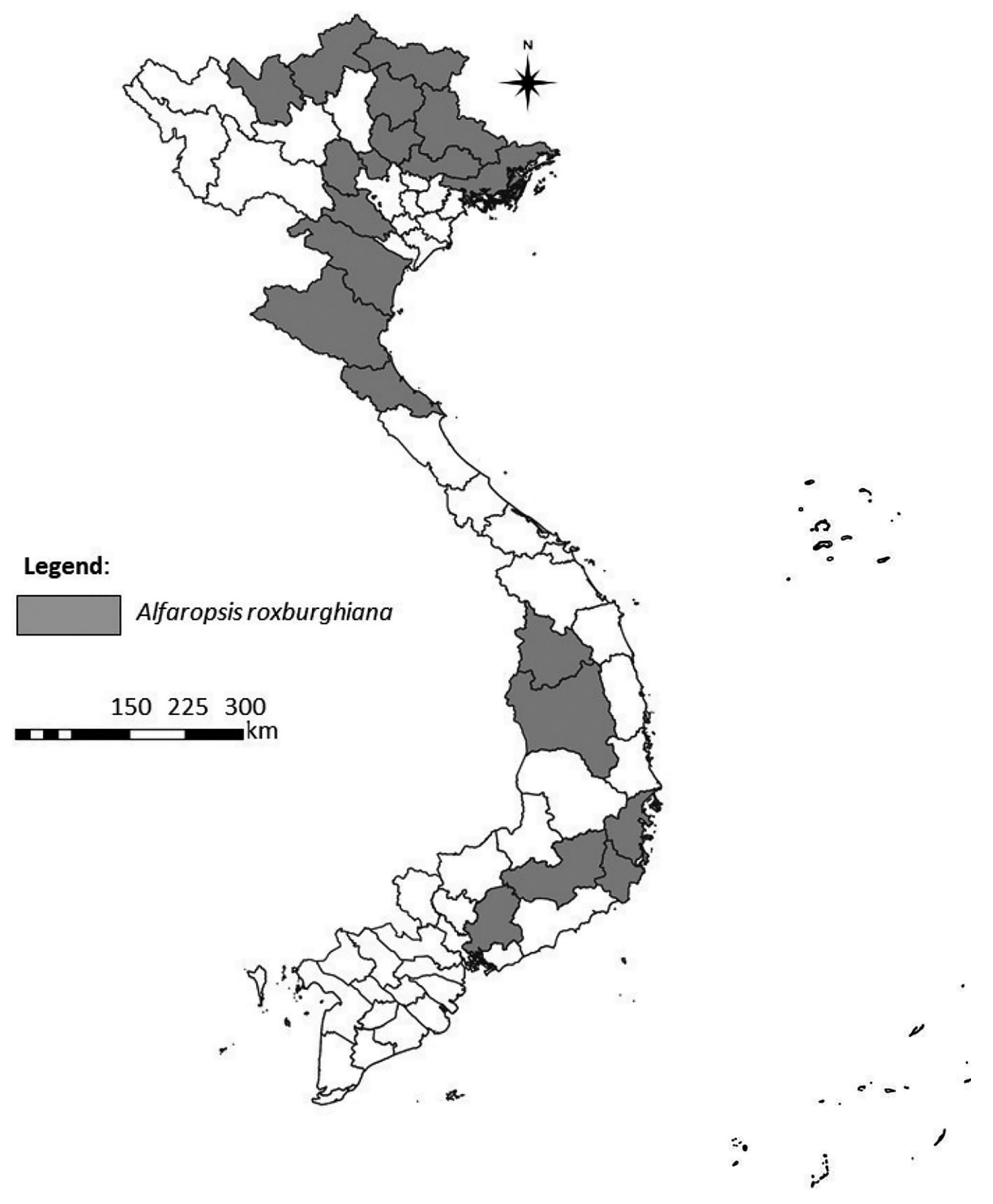

Fig. 1. Distribution map of Alfaropsis roxburghiana in the Vietnamese provinces 
sides, with tufts of hairs at the insertion of the midrib and secondary veins below; secondary veins $13-15$ pairs, clearly visible on both sides; petiolules 3-10 mm. Plant monecious. Male inflorescence lateral, in 2-6 catkins about $11-13 \mathrm{~cm}$, finely pubescent, on a common peduncle of 2-4 $\mathrm{cm}$. Male flowers with one small entire bract or 3-lobed and 2 bracteoles more developed; perianth 4-5 lobed, sepals 4, narrow, on an elongated receptacle; stamens 6-13 connective pointed; anthers hairy, subsessile. Female flowers spiculate, axillary, subsessile; bract and bracteole glabrous; perianth with 4 sepals, tomentose, ovary connate, elongated style; stigma 2-4. Infruitescence 15-30 $(-40) \mathrm{cm}$, winged fruit densely grouped on the axis, sessile. Fruits ovoid, $3 \times 5 \mathrm{~mm}$, hispid hairy, surmounted by persistent style and stigmas; involucre developed in a wing of $2-3 \mathrm{~mm}$ on the ventral side and wing 3-lobed on the dorsal side, with terminal lobe, the largest, $2.4-4.5 \times 0.4-1.2$ $\mathrm{cm}$, glabrous, hispid hairy at the base.
Distribution - Son La, Cao Bang, Lai Chau, Gia Lai, Kon Tum, Lam Dong, Vinh Phuc, Dien Bien, Yen Bai, Ba Ria-Vung Tau, Ha Giang, Lang Son, Quang Ninh, Thanh Hoa, Nghe An, Ha Tinh, Thua ThienHue, Dong Nai and Vung Tau (Con Dao) (Fig. 2).

Habitat and Ecology - A light-demanding tree, found in secondary forests below $700 \mathrm{~m}$ a.s.l. Usually mixed with Elaeocarpus dubius DC. (Elaeocarpaceae), Endospermum sinensis Benth (Euphorbiaceae), Pygeum arboreum Endl. (Rosaceae), and Canarium album (Lour) DC. (Burseraceae) in the middle story of the forest with a forest cover of $0.5-0.6$. Natural regeneration is good in the selectively-logged forests and secondary forests in Cat Tien National Park, Dong Nai province.

Flowering - June to July.

Fruiting - November to December.

Uses - Use for interior furniture, doors, and windows. The bark is used for fish poison. Bark resin is used to treat stomach aches and common colds. Vernacular names - Chẹo lông, Chẹo bông.

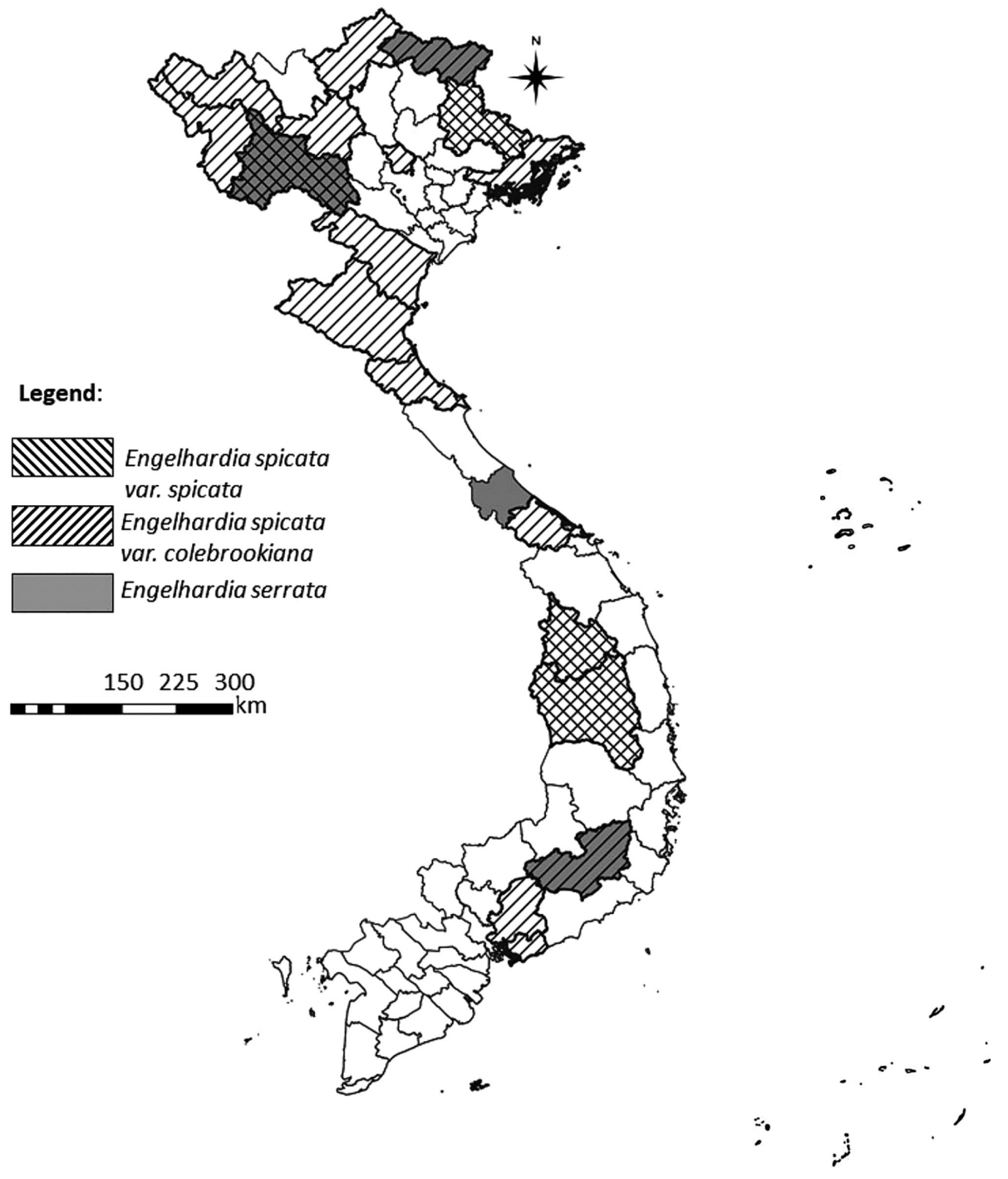

Fig. 2. Distribution map of genus Engelhardia in the Vietnamese provinces 
Engelhardia spicata var. colebrookiana (Lindl. ex Wall.) Koord. \& Valeton, Wall. Pl. As. Rar. iii. 4. t. 208. Engelhardia villosa Kurz, Forest Fl. Burmaii. 491 (1877). Engelhardia spicata var. integra (Kurz) W.E.Manning ex Steenis, Fl. Males., Ser. 1, Spermat. 6(6): 953 (1972). Engelhardia esquirolii H.Lév., Repert. Spec. Nov. Regni Veg. 12: 507 (1913).

Trees $5-10 \mathrm{~m}$ high, trunk up to $30 \mathrm{~cm}$ in diameter. Young twigs brown villous, becoming greyish with many rounded lenticels. Leaves often paripinnate, rachis $15-22 \mathrm{~cm}$ (petioles including), covered in red hair. Leaflets (2-) 5 (5-) pairs, ovate, upper leaflets 7-13 × 3.3-5.7 cm, lower leaflets smaller, asymmetric at the base, obtuse, rounded or retuse at the apex, margin entire, leathery; upper face glabrous, lower face tomentose, with scales glandular \pm abundant, rarely glabrous; secondary veins $8-10$ pairs, \pm prominent below; petiole $5 \mathrm{~mm}$, reddish villous. Male inflorescence in catkins panicles, $4.5-8 \mathrm{~cm}$, at the axil of fallen leaves; male flowers with bracts, bracteoles, and sepals villous; stamens 6-10; anthers densely hairy. Female inflorescence in axillary spikes, sometimes androgynous spikes, with short pedicels, bracts, and bracteoles developed into narrow lobes; style villous; stigmas 2-4. Infrutescence up to $25 \mathrm{~cm}$, with rachis shaggy. Fruits with short pedicels, with style and stigmas persistent. Nuts globose, $4 \mathrm{~mm}$ in diameter, hispid and villous; bracteoles forming a tri-lobed wing on the dorsal side, with median, the largest, $2.0-3.0 \times 0.9-1.25 \mathrm{~cm}$ glabrous, villous hispidwith stinging hairs at the base.

Distribution - Son La, Lang Son, Gia Lai, Kon Tum provinces (Fig. 2). We found three individuals in Xuan Nha Natural Reserve, Son La province, four individuals in Kon Ka Kinh national park, Gia Lai province.

Habitat \& Ecology - Engelhardia spicata var. colebrookiana Lindl. found in humid dense broad leaves forests and broad leaves mixed with pine forests in Xuan Nha Natural Reserve, Son La province at 1200 - 1600 m. In Kon Ka Kinh national park, Gia Lai province, this species occurs in dry forests mixed with Dipterocarpus species at 1000-1200 m.

Flowering - February to March.

Fruiting - February to July.

Vernacular names - Chẹo cánh ngắn

Engelhardia serrata Blume,

Fl. Javae Jugl., t. 2, 5 (1829). Engelhardia palembanica Miq., Fl. Ned. Ind., Eerste Bijv. 3: 346 (1861).

Tree 5-20 m high, trunk up to $50 \mathrm{~cm}$ in diameter. Young twigs with dense brownish pubescent dotted with glandular scales, becoming glabrous and covering with prominent lenticels. Leaves pari- or imparipinnate; rachis $10-18 \mathrm{~cm}$ (petiole $2.7-7 \mathrm{~cm}$ including), brown and hairy. Leaflets (3-) $5(-7)$ pairs, opposite or subopposite, sessile or nearly sessile, ovate, or ovate-oblong to lanceolate, sickle-shaped. Upper leaves $5.5-16.5 \times 2.5 \mathrm{~cm}$. Lower leaves progressively smaller, with crenate margin in the upper half, teeth spaced, curved in the lower part, asymmetrical at the base (slightly more developed acroscopic side); upper surface glabrous with dense hairs on midrib and lateral veins, lower surface hairy reddish, dotted with yellowish glandular scales; secondary veins 11-16 pairs, recessed above, prominent below. Male inflorescences axillary, 2-3 catkins of 2-4 cm. Male flowers subsessile; perianth elongated, with 3 loops; stamens 6, anthers hairy. Female inflorescences in solitary, hanging spikes. Female flowers subsessile, pubescent, stigma 2 . Infructescence up to $20 \mathrm{~cm}$; fruits subsessile. Nuts covered with long stinging hairs; bract expanded, dorsal, 3-lobed, membranous, with a larger median lobe, $2.7-3.5 \times 0.7-1 \mathrm{~cm}$, dotted with glandular hairs and stinging hairs at base; bracteole forming two teeth on the ventral side.

Distribution- Son La, Cao Bang, Quang Tri, and Lam Dong provinces (Fig. 2).

Habitat and Ecology - Occurs in humid dense forests, at low altitudes and up to $1600 \mathrm{~m}$, or in undisturbed mixed dipterocarp and sub-montane forests. On ridges and alluvial sites, usually on poor sandy soils. In secondary forests usually present as a pre-disturbance remnant tree.

Flowering - January to February.

Fruiting - March to May.

Uses - Bark and leaves are rich in tannin and are used as fish intoxicants. The yellowish-white to greyish-red wood is light, soft, and close-grained and is used for the construction of houses. Timber is used for veneer and plywood, turnery, moulding, tool handle, domestic flooring, and general utility furniture. Heartwood is decorative, used for small ornamental items.

\section{Vernacular names - Chẹo}

\section{Juglandoideae Eaton}

\section{Carya Nuttall}

Carya sinensis Dode, Bull. Soc. Dendrol. France 1912, 59. Juglans indochinensis A.Chev., Rev. Bot. Appl. Agric. Trop. xxi. 502.(1941). Annamocarya indochinensis (A.Chev.) A.Chev., Rev. Bot. Appl. Agric. Trop. xxi. 504 (1941). Rhamphocarya integrifoliolata Kuang, Iconogr. Fl. Sin. 1(1): 1, t. 1 (1941).

Trees up to $30 \mathrm{~m}$ high, deciduous, $50-100 \mathrm{~cm}$ in diameter, bole 10-18 $\mathrm{m}$ in height with trunk and buttresses at the base. Bark grayish and glabrous, with prominent lenticels $1.5-2 \mathrm{~mm}$; inner bark 
$2-2.3 \mathrm{~cm}$ thick, white-yellow; broad foliar scars. Twigs horizontal, very gross, scatteredly tomentose. Leaves imparipinnate compound, alternate 30-40 cm long; Rachis 13-30 cm (including petiole), glabrous; petioles $5-7 \mathrm{~cm}$ long, cylindrical, swollen at the base. Leaflets generally 7 , ovate-lanceolate to elliptic, $12-14 \mathrm{~cm}$ long and 5-7 $\mathrm{cm}$ wide, slightly swollen at the base, nearly rounded or asymmetrical, acuminate at apex, margin entire or wavy, glabrous on the two sides with tufts of hair at the insertion of the midrib vein below; secondary veins $15-18$ pairs; petiolule 3-7 (-10) $\mathrm{mm}$. Male inflorescences axillary in fascicles of $5(-8)$ catkins at the base of young shoots; isolated, short stalk or sessile; sepals absent; stamens 5-15. Female inflorescences terminal. Female flowers glandular: perianth formed of 4-6 teeth (bracts and bracteoles fused to the ovary); stigmas 2 . Nuts ovoid, $6-8 \times 5 \mathrm{~cm}$, apiculate-rostrated at the apex; thick exocarp 5-9 mm, dehiscing by $4-6$ valves opening from the top, keeled. Globular to ovoid starch, 3-5 mm long, long rostrum, cavernous in upper part; a cavity in the upper part, 2 in the lower part with incomplete secondary partitions; 3-lobed cotyledons.

Distribution - Bac Kan, Quang Ninh, Lai Chau, Son La, Vinh Phuc, Ninh Binh, and Thanh Hoa provinces (Fig. 3). A total of 33 individuals have been recorded in Cuc Phuong National park, 29 in Ben En National park, and 4 in Xuan Nha natural reserve.

Habitat and Ecology - The species is often found along streams, in valleys (often as a canopy-emergent tree), or at the foot of mountains at 100-600 $\mathrm{m}$. Fruits and seeds are dispersed by water flow (hydrochory). It occurs in plant associations with Sterbulus macrophyllum Blume (Moraceae), Sacara dives Pierre (Fabaceae), Hydnocarpus kurzii (King) Warb. (Achariaceae), Caryodaphnopsis tonkinensis (Lecomte) Airy Shaw (Lauraceae), Pometia pinnata J.R.Forst. \& G.Forst. (Sapindaceae), Dracontomenlum dao (Blanco) Merr. \& Rolfe (Anacardiace-

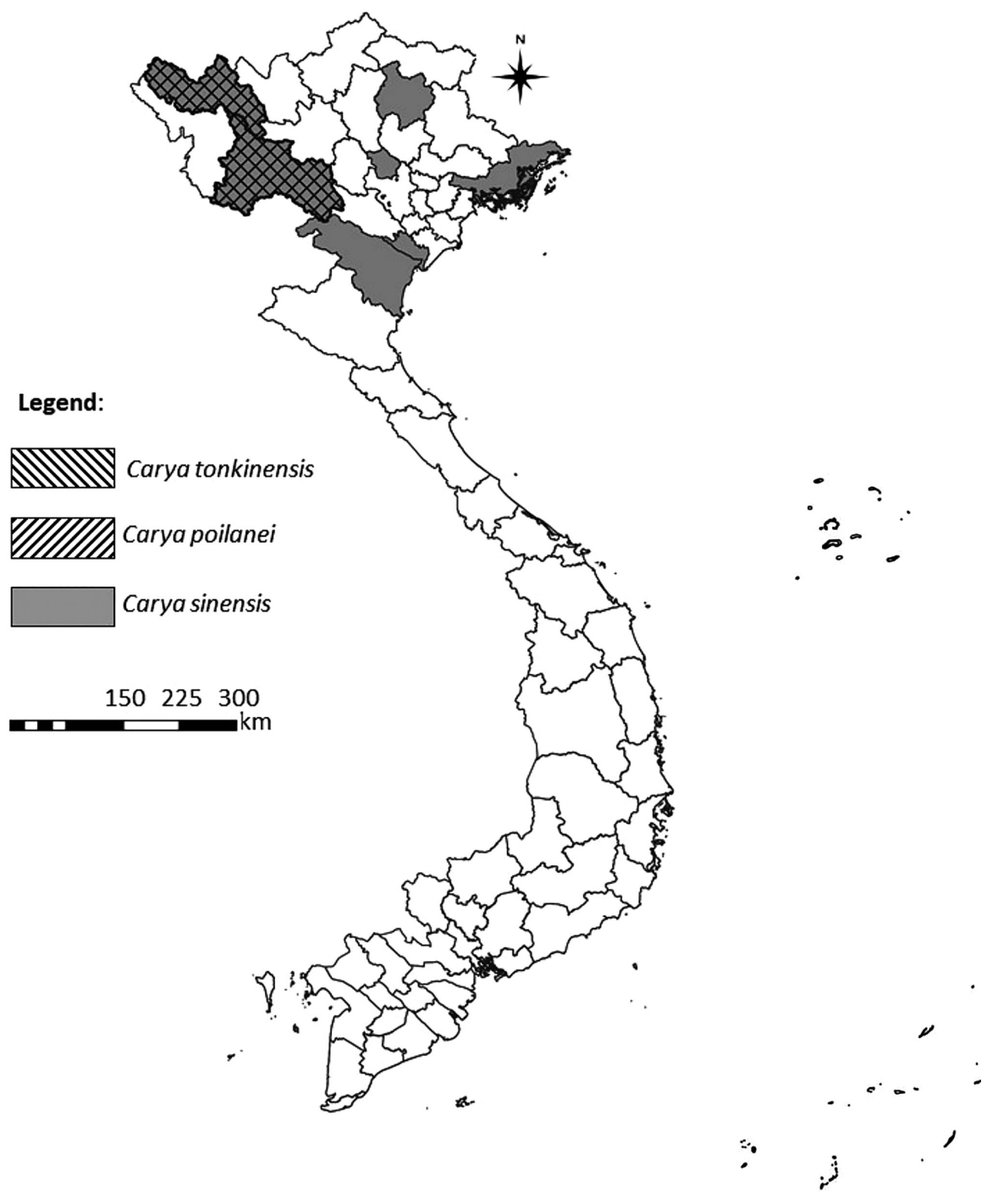

Fig. 3. Distribution map of genus Carya in the Vietnamese provinces 
ae), or Elaeocarpus dubius DC. (Tiliaceae). In Cuc Phuong National Park, this species is found in groups of 3-4 individuals in valleys or sometimes on limestone mountains at an elevation between $100-400 \mathrm{~m}$. The discovery of seedlings suggests that $C$. sinensis reproduces in secondary forests in Cuc Phuong National Park (8 seedlings found) and Ben En national park (29 seedlings found).

Flowering - April to July

Fruiting - July to September.

Uses - It provides good quality wood, used in construction and furniture production. The fruit contains starch used for human food and cattle. The fruit husk is particularly suitable for the production of activated charcoal. Seeds can be pressed for oil and are often planted around lakes in parks as ornamental trees.

Vernacular names - Chò đãi

Carya tonkinensis Lecomte, Bull. Écon. Indochine 1921, xxiii. 2; et in Bull. Mus. Hist. Nat. Parit,1921, xxvii. 438 .

Deciduous tree, medium-sized tree. Trees 10-15 $\mathrm{m}$ high, $50-60 \mathrm{~cm}$ in diameter. Trunk straight, terete. Bark grey-brown or dark gray, flaky. Terminal buds naked and brown. Young twigs covered with glandular red-orange scales, becoming dark brown, with scattered lenticels. Leaves alternate or subopposite; rachis densely covered with glandular scales, along with 7-10 cm petioles. Leaflets 5-7 pairs, opposite, ovate oval or lanceolate-elliptic, the upper leaves are bigger, of $6-15 \times 2,7-5$,2 $\mathrm{cm}$, slightly asymmetrical and sickle-shaped, rounded at the base, apex acuminate or tapering into a sharp point, toothed, with red-orange glandular scales on both sides, denser on below; secondary veins $20-25$ pairs, almost parallel, with tufts of hair at the insertions with the median; petiolule $1 \mathrm{~mm}$, hairy, or none. Midrib tomentose, petiolules very short. Flowers unisexual. Male inflorescences in catkin spike, $10-13 \mathrm{~cm}$, naked at the bottom on $1-1.5 \mathrm{~cm}$, usually having 3 pendulous spikes on terminal leaflets branches; isolated, short pedicellate $5 \mathrm{~mm}$ long, perianth with 2-3 in regular lobes; 3-parted involucre: small bract, oblong, viscous bracteoles; stamens 4-7, short filaments, hairy anthers, $1 \mathrm{~mm}$ long. Female inflorescences spike at the terminal. Female flowers, perianth forms cup-shaped with 4 irregular dents (bract and bracteole welded to the ovary); ovary inferior, unilocular; almost no style; stigmas 2 , median, fleshy, fluffy. Fruits drupe, ovoid, $3 \times 2,5$ $\mathrm{cm}$ slightly depressed at the base and the top, epicarp dehiscent by 3-4 fleshy valves, uneven, scaly at the apex. Endocarp $1 \mathrm{~mm}$ thick, depressed at the top; ovary 3 locules, one at the top, 2 at the bottom part with incomplete partitions making the cotyledons 3-lobes. Pericarp thick, upper part 1-celled, lower part 4-celled, endosperm with copious oil.

Distribution - This species is distributed in small areas in northern provinces, especially along Da river banks and in Lai Chau and Son La provinces (Fig. 3). During our study, a total of 12 individuals were recorded (7 in Xuan Nha natural reserve and 5 in Thuan Chau natural reserve, Son La province).

Habitat and Ecology - Carya tonkinensis is a light-demanding tree, moist, deep soils and grows between $600-1200 \mathrm{~m}$. It also grows in secondary or regenerated forests in former shifting cultivation areas. It is a fast-growing tree and its natural regeneration is good.

Flowering - March to May.

Fruiting - July to August.

Uses - Used for construction and furniture. The edible seeds are tasty and can be used for the production of high-quality and sweet oil. Fruit skins are used for activated charcoal production.

Vernacular names - Mạy châu, Hồ đào núi, Hồ đào bắc bộ.

Carya poilanei (A.Chev.) J.-F.Leroy, Rev. Int. Bot. Appl. Agric. Trop. xxx. 428 (1950). Juglans poilanei A.Chev., Rev. Bot. Appl. Agric. Trop. xxi. 496 (1941).

Trees $12-15 \mathrm{~m}$ height, trunk $40-50 \mathrm{~cm}$ in diameter. Twigs blackish, with sparse lenticels, with persistent foliar scars, broad; foliar buds glandular, reddish and pubescent. Leaves alternate, persistent; Rachis $12-20 \mathrm{~cm}$ (petiole including), glabrous; Leaflets 5, ovate, upper $25-35 \times 10-13 \mathrm{~cm}$, lateral smaller, obtuse to cuneate at base, slightly asymmetrical (acroscopic side more developed), obtuse-acuminate at the apex, margin serrulate, glabrous on both sides, but with tufts of hair at the insertion of the secondary veins with the median below; secondary veins (12-17) pairs almost parallel, prominent on both sides; tertiary nervation well visible below, petiolule 3-6 $\mathrm{mm}$. Fruits globose to ovoid, not depressed. Endocarp $2.2-2.4 \times 2.1-2.2 \mathrm{~cm}$, smooth outer, slightly hilly, $4 \mathrm{~mm}$ thick, not pointed; cotyledons 3- lobed.

Distribution-Lai Chau and Son La provinces (Fig. $3)$.

Habitat and Ecology - Carya poilanei (A.Chev.) J.-F. Leroy found in the high altitude of rainforests and on limestone mixed soils forest at $1500 \mathrm{~m}$ a.s.l.

Flowering - April to June

Fruiting - August to December.

Uses - The nutmeat is not edible. Timber can be used for making furniture.

Vernacular names - Mạy châu poilanei 
Platycarya Siebold \& Zucc.

Platycarya strobilacea Siebold \& Zucc., Abh. Math.Phys. Cl. Königl. Bayer. Akad. Wiss. 3(3): 743, t. 5 (1843). Fortunaea chinensis Lindl., J. Hort. Soc. Londoni. (1846) 150. Platycarya longipes Wu, Bot. Jahrb. Syst. 71(2): 171 (1940).

A deciduous, medium-sized tree, up to $15-20 \mathrm{~m}$ in height and $40 \mathrm{~m}, 50 \mathrm{~cm}$ in diameter but often found as smaller sized trees. Bark ash-grey, irregularly longitudinally fissured. Young branches terete, brown initially densely pubescent, later glabrescent. Old branches brown, glabrous with elliptic lenticels. winter buds ovoid, axillary, brown. Buds scales numerous, triangular, 5-7 $\mathrm{mm}$ long, margin ciliate. Crown globose and thin. Leaves odd-pinnate, alternate, $15-35 \mathrm{~cm}$ long (sometimes $45 \mathrm{~cm}$ ) petiole terete, slightly pubescent, dilated at the base with 7-23 leaflets. Leaflets opposite or subopposite, subsessile, $4-12 \mathrm{~cm}$ by $2-4 \mathrm{~cm}$, lanceolate-ovate or lanceolate elliptic, attenuate toward tip, base subrounded, oblique, margin clearly serrate, dark green and glabrous above, greenish beneath, and pubescent at axils of veins. Penninerved, lateral veins 10-12 pairs or more.

Flowers unisexual, minute, naked, arranged into catkin-spikes. Male catkins 6-10 cm long, many flowered, erect, terminal (rarely axilary), stalk $2 \mathrm{~cm}$ long, brown pubescent, stamens often 8 , the length of filament unequal; anthers yellow, globose, 2-celled. Female catkins about $2 \mathrm{~cm}$ long, subglobose or ovoid, stalk $6 \mathrm{~mm}$ long with brown tomentum, often occurs above the male catkins. Bracts broadly ovate, acute; ovary flat, style short; stigma bifid, pubescent. Infructescence subglobose, brown, $3-4 \mathrm{~cm}$ long, $2-3 \mathrm{~cm}$ wide. Fruits borne in cone-like structures bearing small two-winged nutlets, about $5 \mathrm{~mm}$ long and yellow-brown.

Distribution - Bac Kan, Cao Bang, Ha Giang, Hoa Binh, Lao Cai, Thanh Hoa, Tuyen Quang, Son La, Lang Son, Ninh Binh, and Phu Tho provinces

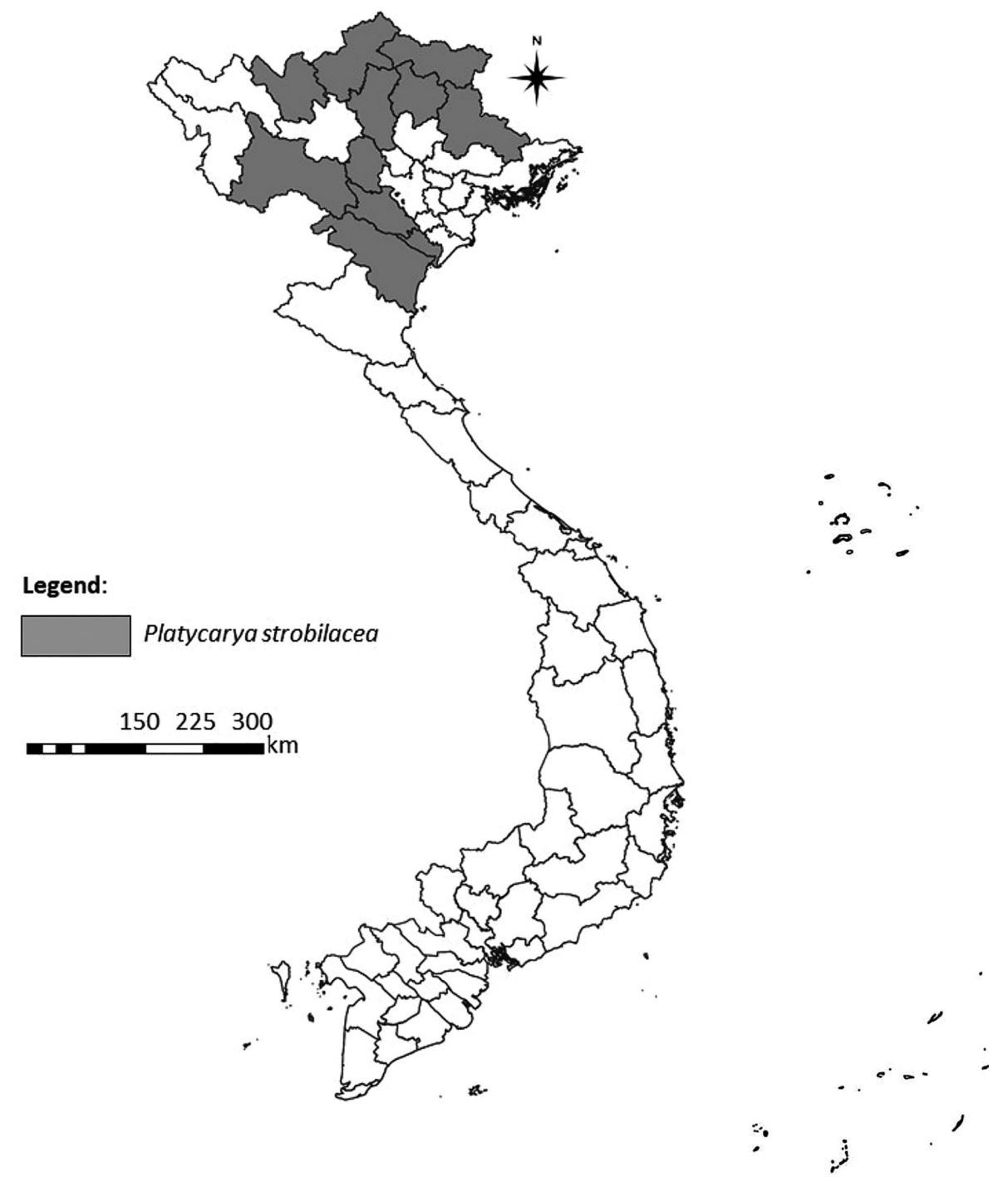

Fig. 4. Distribution map of Platycarya strobilacea in the Vietnamese provinces 
(Fig. 4). A total of 19 mature trees and 16 seedlings were recorded during our field survey in Xuan Nha natural reserve and Cuc Phuong National park.

Habitat and Ecology - Usually found between 400$1200 \mathrm{~m}$ a.s.l., growing mainly on limestone soil, with medium humus content and a neutral to slightly neutral $\mathrm{pH}$. Often mixed with Illicium verum, Schefflera octophylla, Acer decandrum, Fagaceae, and Lauraceae species, forming a forest type characteristic of mountain vegetation on limestone geology. In Cuc Phuong national park, Platycarya strobilacea was only found growing as scattered individuals $400 \mathrm{~m}$ on the peak of a limestone mountain called Cloudy Silver Peak. In Xuan Nha Natural reserve, Son La province, this species is found on limestone soil from $400-700 \mathrm{~m}$.

Flowering - April to May.

Fruiting - August to September.

Uses - wood used for furniture production; the leaves can be used as insecticides and as a skin remedy. The bark and roots are rich in tannins. Fruits and bark are used to dye fabrics. Fruits and leaves can treat some common diseases, such as tendons, bones, and abdominal pain, rash, and eczema.

Vernacular names - Hóa hương, Hương núi.

\section{Pterocarya Kunth}

Pterocarya tonkinensis (Franch.) Dode, Bull. Soc. Dendrol. France 67 (1929). Pterocarya stenoptera var. tonkinensis Franch., J. Bot. (Morot) 12 (21): 318 (1898).

Deciduous tree, medium-sized tree, up to 20-25 $\mathrm{m}$ high, sometimes $>30 \mathrm{~m}, 50-60 \mathrm{~cm}$ in diameter. Trunk straight, terete. Bark grey-brown or dark gray, flaky. Twigs brown or yellowish-brown with yellow scattered hairs. Leaves odd-pinnate compound, alternate. Petioles with yellow scaled hairs, glabrescent. Leaflet 5-7, opposite, ovate oval or lanceolate-elliptic; apex acuminate or tapering into a sharp point, margin serrulate;

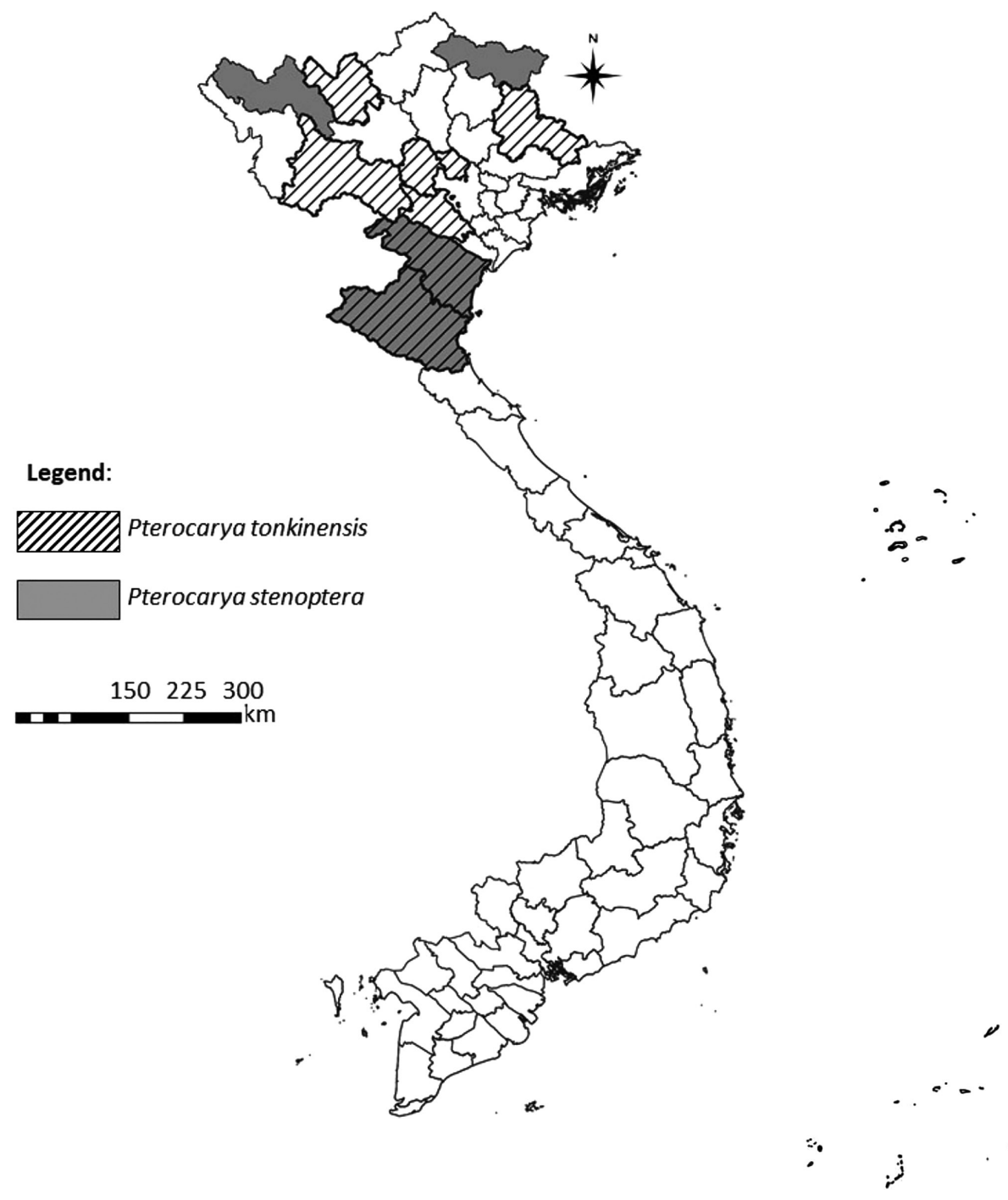

Fig. 5. Distribution map of genus Pterocarya in the Vietnamese provinces 
terminal leaflets are big, lanceolate, gradually attenuate toward both ends, base cuneate; two basal leaflets are small and asymmetric; midrib tomentose, petiolules very short. Flowers unisexual. Male inflorescence is a catkinspike, usually having 3 pendulous spikes on terminal leaflets branches; male flowers with pedicels $5 \mathrm{~mm}$ long, perianth with 2-3 in regular lobes. Stamens 5-6, in 2 whorls, filaments short. Female inflorescence short, few-flowered. Female flowers perianth cup-shaped with 4 irregular dents, tomentose outside, ovary inferior without style, stigmata 2 . Fruits a bi-winged nutlet, $2.8 \mathrm{~cm}$ in diameter with 4 grooves later dehiscing into 4 valves. Pericarp thick, upper part 1-celled, lower part 4-celled, endosperm with copious oil.

Distribution - Nghe An, Hoa Binh, Vinh Phuc, Son La, but also present in Lang Son, Lao Cai, Phu Tho, and Thanh Hoa provinces (Fig. 5).

Habitat and Ecology - Found of moist, sandy soil usually growing on riverbanks and streambanks on alluvium, between 500-1000 m. Commonly growing in pure stands or mixed with Elaeocarpus thorelli Pierre (Elaeocarpaceae) and Cleisocalyx consperpunctatus L. (Myrtaceae). Natural and coppice regeneration is strong. Entirely deciduous tree: November - December.

Leafing and flowering - March to April.

Fruiting - April to May.

Uses - Use for spars and general utensils. The bark can treat toothache, common scabies, trichomonas. The bark and leaves are rich in tannin. Leaves and seeds are used as fish-poison, insecticide, and skin-cured diseases such as scabies.

Vernacular names - Cơi, Cơi bắc bộ.

Pterocarya stenoptera C.DC., Ann. Sci. Nat., Bot. sér. 4, 18: 34 (1862). Pterocarya stenoptera var. zhijiangensis Z.E.Chao \& C.J.Zheng, Acta Phytotax. Sin. 20(1): 119 (1982). Pterocarya chinensis Hort. ex Lavall., Arbor. Segrez. 65. Pterocarya esquirolii H.Lév., Cat. Pl. Yun-Nan 135, in adnot. (1916). Pterocarya laevigata Hort. ex Lavall., Arbor. Segrez. 65. Pterocarya japonica Hort. ex Dippel, Handb. Laubholzk. ii. (1892) 329, fig. 19; Koehne, Deutsche Dendrol. (1893) 74.

Trees up to $20-25 \mathrm{~m}$. Bark smooth when young, deep slits when aged. Twigs glabrous and blackish. Buds terminal and naked. Leaves compound, even pinnate, rarely odd-pinnate; Rachis of 15-25 cm (petioles including), narrowly winged on leaves of young shoots, or sometimes only ridged or sulcate on leaves. Leaflets 4-8 pairs, opposite, ovate, superiors 8-9,5 $\times 3-3,5 \mathrm{~cm}$; inferiors are smaller, slightly asymmetrical at the base (the side opposite the base more rounded), obtuse, sometimes acute or acuminate at the apex, membranous, with dentate margin, sessile, glabrous on both sides or little hairy on the veins below, secondary veins 15 pairs approx. Male inflorescence in dense catkins, of 6-8 cm. Female inflorescence of $6-18 \mathrm{~cm}$, with looser flowers. Male flowers, bracts, and bracteoles arranged in spatula 3-lobed, with a dorsal surface covered with glandular scales, stamens 8-10, with very short or no filament; anther binocular and glabrous. Female flowers, bracts smaller than bracteoles, all covered dorsally with glandular scales, sepals 4, glabrous; adhered to the ovary by the base. Fruits slender, spike, and very long of $25-30 \mathrm{~cm}$. Nuts long ellipsoid of 6-7 $\mathrm{mm}$, with linear 2 wings of $15-17 \times 3-4 \mathrm{~mm}$, at the variable angle of divergence.

Distribution - Nghe An, Thanh Hoa, Lai Chau, and Cao Bang provinces (Fig. 5).

Habitat and Ecology - Prefers warm, temperate, and subtropical zones with deep, moist, well-drained soil, but does well in dry, exposed sites and heavy clay. Trees can be found in the forests, often near the edge of streams, from 100-400 m.

Uses - The bark can treat toothache, common scabies, trichomonas.

Vernacular names - Cơi, Ngón.

\section{Juglans L.}

2.4.1 Juglans regia L., Sp. Pl. 2: 997 (1753). Juglans duclouxiana Dode, Bull. Soc. Dendrol. France 1909, 1906, 81. Juglans regia subsp. sinensis (C.DC.) Ohle, in R. Mansfeld, Verz. Landwirtsch. u. Gartn. Kulturpfl., Auf. 2, ed. J. Schultze-Motel 1: 38 (1986). Juglans sinensis (C. DC.) Dode, Bull. Soc. Dendrol. France 1906, 92.

A large tree 10-15 (-30) $\mathrm{m}$ high and $80 \mathrm{~cm}$ in diameter. Trunk straight, cylindrical, crown large. Bark ash-grey or dark-grey, not fissured when young, longitudinal fissures on old stems. Twigs knotty, gray, and glabrous. Buds covered with scales. Leaves alternate, imparipinnate, caducous. Rachis $15-20 \mathrm{~cm}$ (petiole including), glabrous. Leaflets 5-11, opposite to subopposite, the upper leaflets bigger, 6,5-15 $\times 3-7 \mathrm{~cm}$, glabrous on both sides, but with strong tufts of hair at axils of the secondary veins with the median below; margin entire, nearly sessile; apex acute. Plants unisexual, monoecious. Male inflorescence in catkin-spike of 7-10 cm. Male flowers stalked; perianth forming 5-6 lobes dorsally hairy; stamens 14-25; anther glabrous. Female inflorescence in upright spikes with 1-4 flowers. Female flowers hairy and glandular scaly; ovary inferior and tomentose; stigma 2 , divergent, green. Infrutescence carrying 1-3 drupes, globular to ovoid, 4-6 $\mathrm{cm}$ of diameter. Epicarp with irregular dehiscence; endocarp \pm carved, dehiscent to germination by 2 valves; a locule at the top, 2-4 locules at the bottom by the 
development of the secondaries; cotyledons cerebellar, 4-lobes, with oil reserves.

Distribution - Introduced to Cao Bang, Lai Chau, Lao Cai, Dien Bien, and Ha Giang provinces in Northern Vietnam (Fig. 6).

Habitat and Ecology - Cold temperate species, often found growing in valleys, at the foot of mountains, or on former shifting cultivation land between $600-1500 \mathrm{~m}$. Natural regeneration is rather good on open land.

Flowering - April to May.

Fruiting - September to November.

Uses - The bark and roots can treat dysentery, chronic enteritis, diarrhea, and rectal prolapse. Its wood is used to make gun-stocks, ammunition, carving stock, and furniture. Trunk bark and fruits contain tannin. Leaves have antiseptic properties. Seeds can be eaten or pressed for oil. The seeds are used as a medicine for asthma, cough, enhance strength, as a diuretic, for skin problems, or eaten as food. Leaves can be used as antisep- tics. In some countries, leaves are used to treat herpes, eczema and leucorrhoea.

Vernacular names - Óc chó, Hồ Đào.

\section{Rhoipteleoideae Reveal.}

\section{Rhoiptelea Diels \& Hand.-Mazz}

3.1.1 Rhoiptelea chiliantha Diels \& Hand.-Mazz, Repert. Spec. Nov. Regni Veg. 30: 77 (1932).

Medium trees up to $20 \mathrm{~m}$, deciduous, $30-40 \mathrm{~cm}$ diameter of the trunk. Bark gray. Young branches, stipules, rachises, petioles, and inflorescences densely covered with yellowish-white glands and pubescent. Branchlets densely covered with brownish yellow lenticels. Stipules leaflike, 3-6 $\mathrm{mm}$, sessile. Petiole 3-4 cm. Rachis sulcate and pubescent. Leaves odd-pinnate, $15-30 \mathrm{~cm}$ long, including 7-19 leaflets, leaf blade 15-30(-40) $\mathrm{cm}$; abaxially pubescent and glandular on veins or vein axils, adaxially pubescent on midvein; lateral leaflets oblong-lanceolate, proximal ones shorter,

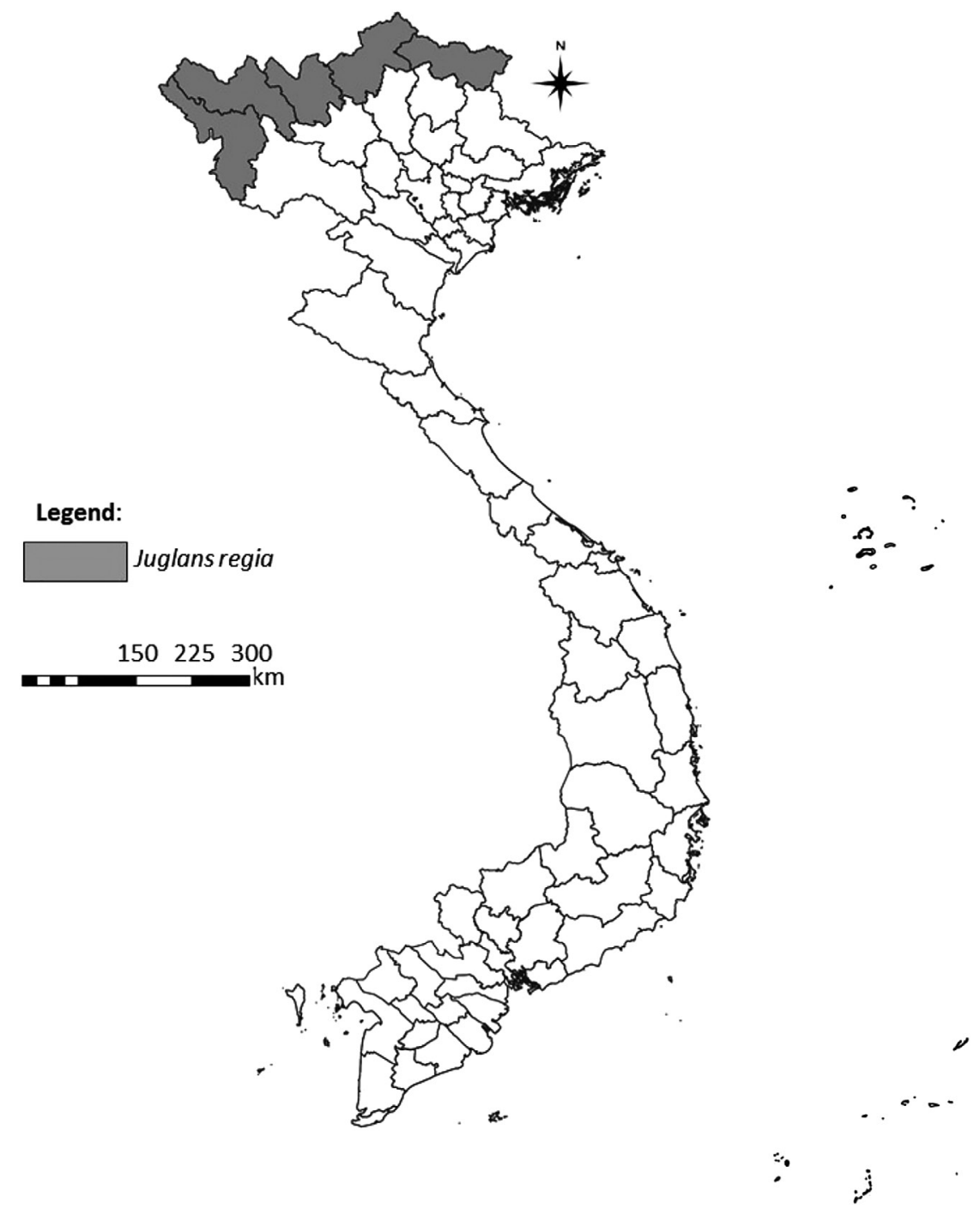

Fig. 6. Distribution map of Juglans regia in the Vietnamese provinces 
oblique, elliptic-ovate; terminal leaflet lanceolate; secondary veins (9-)14-20 on each side of the midvein. Inflorescence branches $15-30(-38) \mathrm{cm}$, in catkin, axillary in distal leaves, many spikes in fascicles. The large panicles of compound catkins nodding from the shoot apex look like a horsetail. Flowers small and inconspicuous; tepals 4, brown; pistil 1, no staminode; styles 2, branched; anthers 6, short, and filantherous; stigmas 2, white when receptive; ovary 2-loculed, only one developed. Nutlets brownish yellow when mature, obpyriform, slightly compressed, 2-3 mm, with grayish-brown glands, 4-ribbed on each side; wings rounded to ellipsoid, 5-8 mm wide; mesocarp brown, woody, irregularly verrucose; endocarp white. Seeds fleshy, elliptic, ca. $2 \mathrm{~mm}$.

Distribution - China in the provinces of Guangxi and Yunnan and in Vietnam (Kozlowski et al. 2018). Previously it has been described as endemic to China. However, we found this species in a small area in Lai Chau (Ta Phin, 11 trees), Lao Cai
(Hoang Lien National Park, Sapa, 28 trees), Cao Bang (Phia Den Natural Reserve, 12 trees), and Yen Bai provinces (Fig. 7). Natural regeneration of this species is not good in these areas, only 18 seedlings were found in the study sites.

Habitat and Ecology - grows in mixed mesophytic forests and evergreen broad-leaved forests on hill slopes, in valleys, and on riversides, between 700 and $2500 \mathrm{~m}$ a.s.l.

Flowering - October to January.

Fruiting - July to August.

Uses - Wood is light gray, light, soft, used for ordinary woodwork. The husk and fruits contain a lot of tannins and are used for dyeing purposes.

Vernacular names - Đuôi chó, Đuôi ngựa

Taxonomic diversity and distribution - The Juglandaceae of Vietnam comprises 10 native and one introduced species (Juglans regia) that is widely cultivated. The members of the Walnut family are largely distributed throughout Vietnam. However, the highest concentration of species is found

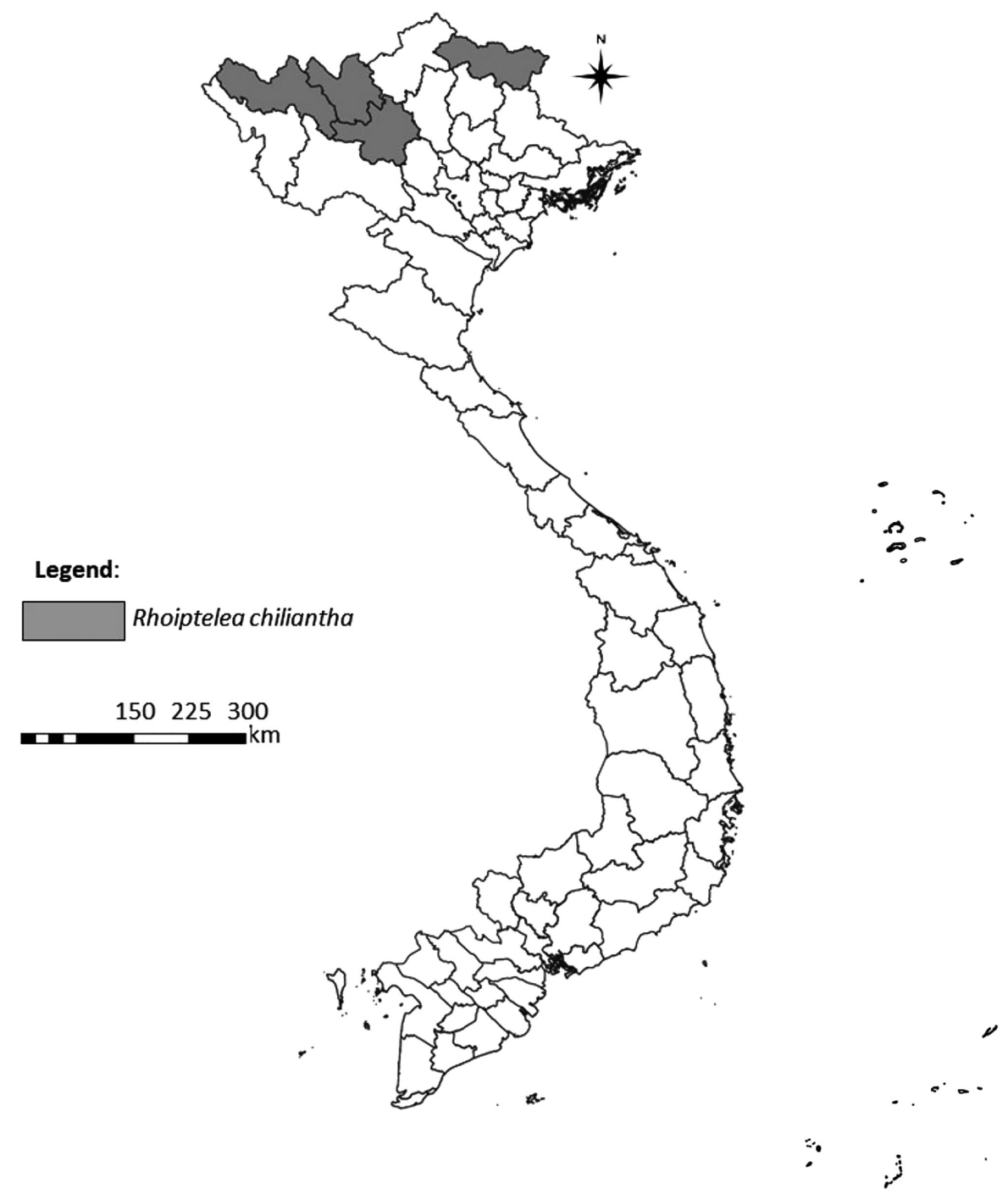

Fig. 7. Distribution map of Rhoiptelea chiliantha in the Vietnamese provinces 
in the rain-laden mountains of Northern Vietnam (Son La, Lai Chau, and Lao Cai provinces) (Fig. 8). In the central and the southern parts of Vietnam, the mountainous provinces of Kon Tum, Gia Lai, and Lam Dong also host numerous species. Alfaropsis roxburghiana is the most widespread species in Vietnam, with a presence noted in 20 provinces (Fig. 1), while Carya poilanei and C. tonkinensis are the rarest, as they are present in only 2 provinces (Fig. 3). Carya poilanei, known originally only in Vietnam thanks to a herbarium specimen collected in 1937, was discovered recently in the Son La province. Most Vietnamese Juglandaceae taxa are found between 600 and $1200 \mathrm{~m}$, although some are found at sea level (Engelhardia spp.) or up to $2500 \mathrm{~m}$ (Rhoiptelea chiliantha), with a rather broad amplitude (Fig. 9).

Uses - All species of Juglandaceae found in Vietnam are useful plants (Table 2). Most of them are used for woodwork and furniture, but mostly at a local or regional level (e.g. Rhoiptelea, Engelhardia, Juglans, Carya). Although seed kernels of many Juglandaceae species are eaten used to extract oil worldwide, only a few species are used for this
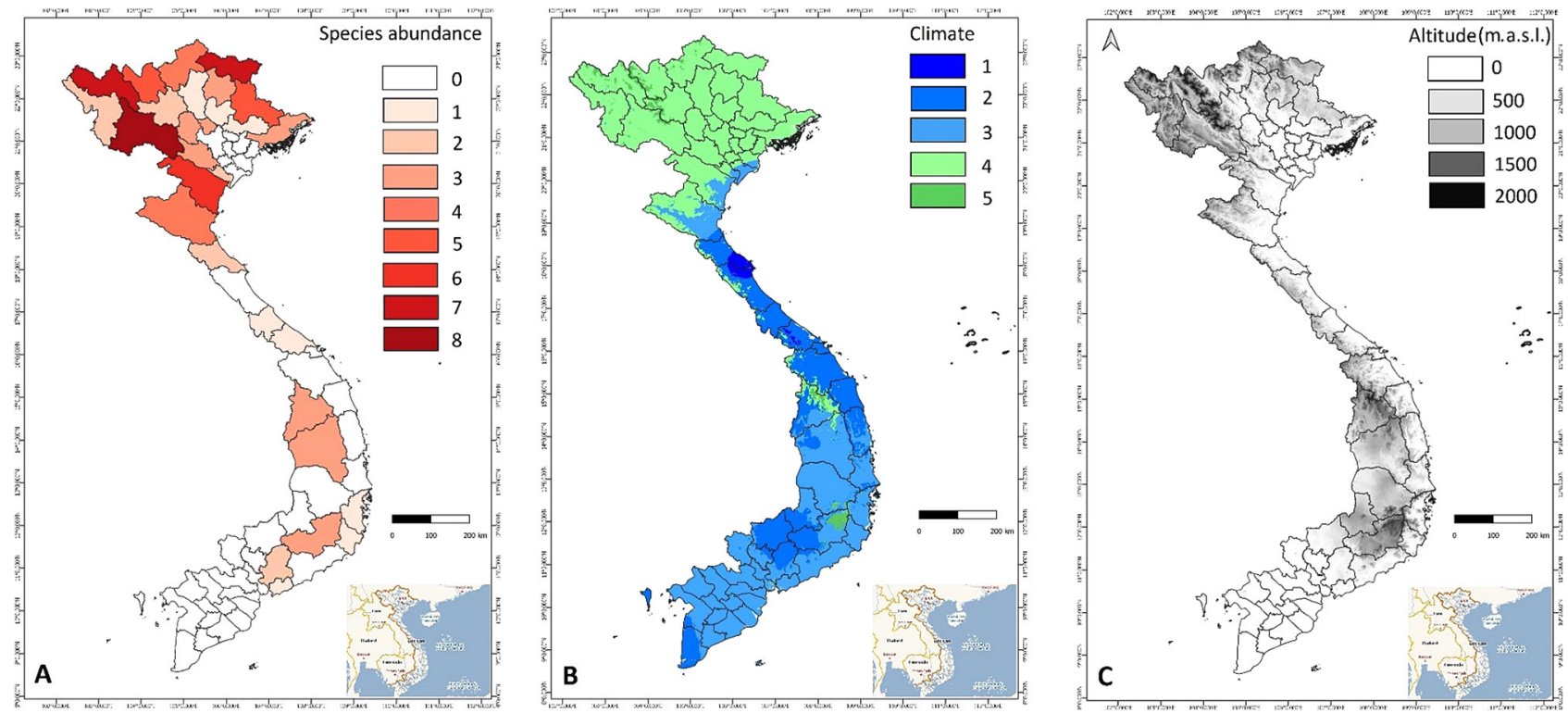

Fig. 8. (A) Species abundance of Juglandaceae in Vietnam (0-8 species per province), (B) climatic map: 1. tropical, rainforest, 2. tropical, monsoon, 3. tropical, savannah, 4. temperate, dry winter, hot summer, 5. temperate, dry winter, warm summer and comparison with (C) relief

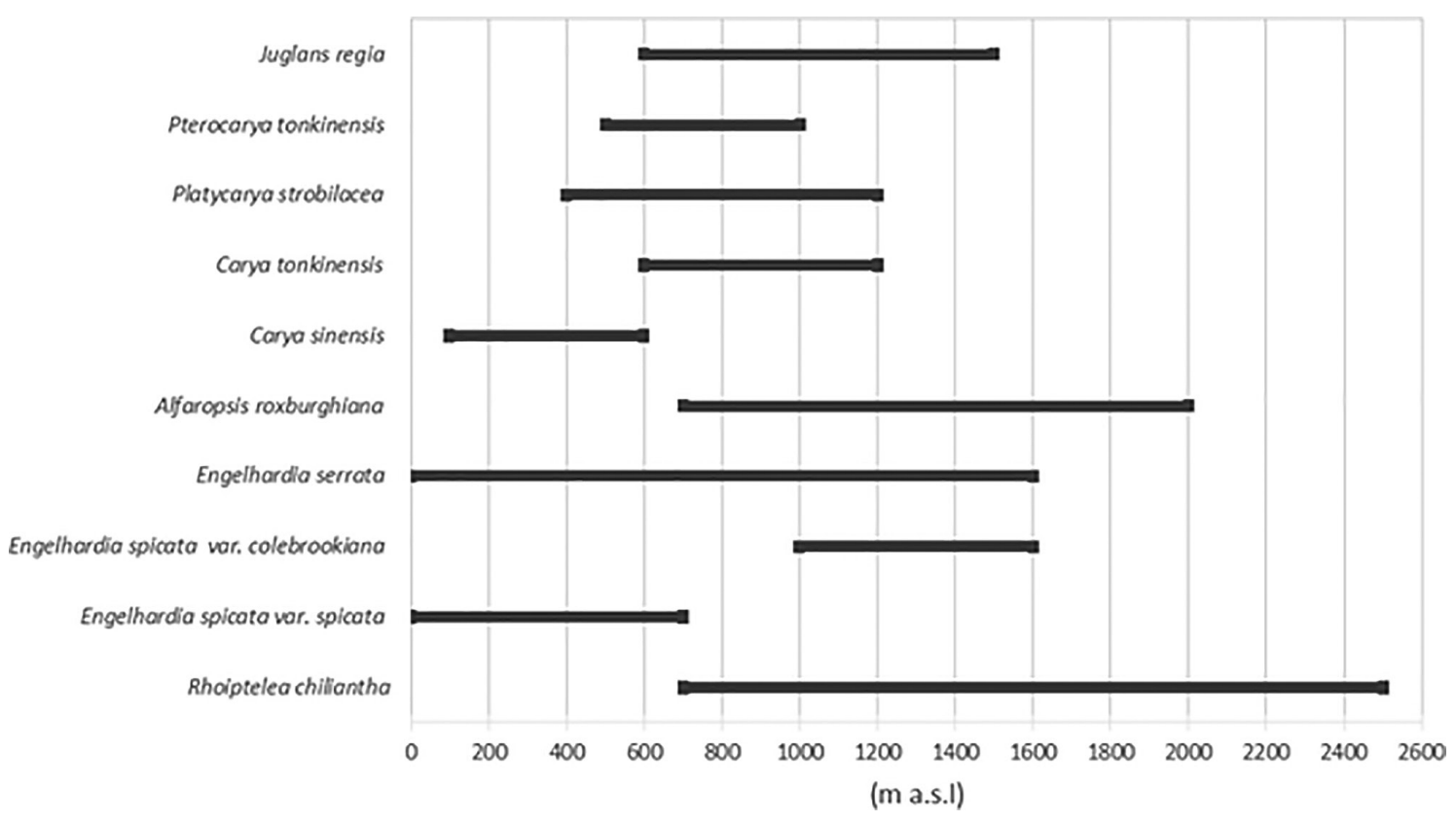

Fig. 9. Altitudinal distribution of Juglandaceae in Vietnam (no data for Carya poilanei and Pterocarya stenoptera) 
Table 2. Uses of Juglandaceae in Vietnam

\begin{tabular}{|c|c|c|c|c|c|c|c|c|}
\hline Taxon & Forestry & Woodwork & Food / fruits & Oil & $\begin{array}{l}\text { Tanning / } \\
\text { staining }\end{array}$ & Poisoning & $\begin{array}{c}\text { Ornamental } \\
\text { trees }\end{array}$ & $\begin{array}{l}\text { Traditional } \\
\text { medecine }\end{array}$ \\
\hline Rhoiptelea chiliantha & & $x$ & & & $\times$ & & & \\
\hline Engelhardia spicata var. spicata & & $x$ & & & & $x$ & & $x$ \\
\hline \multicolumn{9}{|c|}{ Engelhardia spicata var. colebrookiana } \\
\hline Engelhardia serrata & $x$ & $x$ & & & & $x$ & & \\
\hline Alfaropsis roxburghiana & $x$ & $x$ & & & & $\times$ & & \\
\hline Carya sinensis & & $x$ & $x$ & $x$ & & & & $x$ \\
\hline Carya tonkinensis & & $x$ & $x$ & $x$ & & & & \\
\hline Carya poilanei & $x$ & & & & & & & \\
\hline Platycarya strobilacea & & $x$ & & & & $x$ & & $x$ \\
\hline Pterocarya tonkinensis & & $x$ & & & & $x$ & & $x$ \\
\hline Pterocarya stenoptera & $x$ & & & & & & $x$ & $x$ \\
\hline Juglans regia & & $x$ & $\times$ & $\times$ & & & & $\times$ \\
\hline
\end{tabular}

purpose in Vietnam (e.g. Carya sinensis, C. tonkinensis, Juglans regia). The most common application is to use crushed leaves and bark, which contain a wide range of chemicals to stun fish, for fishing (Kozlowski, Bétrisey \& Song 2018). This mainly concerns Engelhardia spp., Alfaropsis roxburghiana, Pterocarya tonkinensis, and Platycarya strobilacea. The pharmacological properties of Juglandaceae have long been recognized and widely used in traditional medicine at a local level. For example, the bark resin of Engelhardia spicata is commonly used to treat stomachache, while fruits and leaves of Pterocarya strobilacea are effective against some common diseases, such as painful tendons, eczema, and rash. Juglans regia is probably the most interesting species from a therapeutic perspective and is used to treat dysentery and diarrhea. Its fruits are used to treat asthma, cough or are used for skin care.

Threats and conservation status - Three species occurring in Vietnam are classified as globally threatened according to the IUCN Red List (Rhoiptelea chiliantha, Carya sinensis, and Pterocarya tonkinensis), while four are classified as least concerned (Engelhardia spicata, E. serrata, Alfaropsis roxburghiana, Pterocarya stenoptera). Additionally, one species (Carya tonkinensis) is threatened locally and listed as vulnerable (VU) according to the Vietnam Red Data Book. Two more taxa merit to be included in the Vietnam Red Data Book (Engelhardia spicata var. colebrookiana and Platycarya strobilacea). The most frequent threats are linked to human activities and include land-use change and habitat destruction (e.g., logging, artificial wood plantations, road constructions, etc.). During our field studies based on the herbarium specimen of Carya poilanei collected by Poilane on 31 December 1937, we did not found any individual of this species in Lai Chau province. Two specimens have been found in Son La province recently. Further fieldwork and studies are needed to assess the threat situation of this species.

\section{Discussion}

Vietnam, with its complex topography and diversity of climatic conditions, hosts many endangered plants. With 12,300 known vascular plants, including around 1,500 tree species, Vietnam is one of the most biodiverse countries on Earth. The country is also one of the Walnut family diversity centers worldwide. With 11 known species representing seven genera and all three subfamilies, it takes the prominent second place just after China (Kozlowski et al. 2018; Song et al. 2020a).

The rainy mountains of Northern Vietnam, areas with their best-preserved forest cover, are the most diverse areas for Juglandaceae (Pham, 2003; Song et al., 2020a). Notably, Rhoiptelea chiliantha, Platycarya strobilacea, Carya tonkinensis, C. sinensis, and C. poilanei are almost exclusively found in this northern part of Vietnam. In contrast, Alfaropsis roxburghiana and the two Vietnamese Engelhardia species (E. serrata and E. spicata, the last with two varieties) can be found from the North to the South, at higher elevations. The two Pterocarya species are known from the country, $P$. stenoptera and $P$. tonkinensis, growing in lowland riparian forests, mainly in the northern part of the country (Kozlowski, Bétrisey \& Song 2018). Besides our present study, new and intensive fieldwork is needed to improve the knowledge of the Vietnamese species as well as distribution data on Juglandaceae of Southeastern Asia. This is especially the case in taxonomically complex Engelhardia (Zang et al., 2020) but also in Pterocarya Song et al., 2020b; Zhang et al., 2020).

The Juglandaceae family has an inestimable economic and conservation value (Kozlowski, Bétrisey \& Song 2018; Song et al., 2020a). All Vietnamese Juglandaceae species are important useful plants. Since all members of Juglandaceae are trees, nearly all species are used by local communities for timber production and woodwork. Carya tonkinensis, C. sinensis, and introduced Juglans regia are widely used 
for fruit production and oil extraction. Many species are used in traditional medicine (e.g. Pterocarya spp., Platycarya strobilacea, or Carya sinensis), as well as for fish poisoning (e.g. Pterocarya, Alfaropsis, and Engelhardia spp.) (Pham, 2003; Tran \& Nguyen, 1993).

Vietnam possesses an enormous international responsibility for Juglandaceae conservation. This is especially the case for globally threatened and phylogenetically isolated Rhoiptelea chiliantha and Carya sinensis. Both species are classified as endangered (EN) in the IUCN Red List. Two further Juglandaceae need more conservation efforts: Pterocarya tonkinensis, which is globally vulnerable (VU), and Carya tonkinensis, which is locally vulnerable (VU) (Ban, 2007). Additionally, our present study revealed that the remaining populations of Platycarya strobilacea and Engelhardia spicata var. colebrookiana are threatened as well in Vietnam. To summarizing, half of the Vietnamese Juglandaceae are globally and/or locally threatened and would need a coordinated protection plan and enhanced conservation efforts.

\section{Acknowledgments}

This research is funded by Vietnam National Foundation for Science and Technology Development (NAFOSTED) under grant number 106.062018.23 and supported by the Institute of Dendrology, Polish Academy of Sciences. The authors would like to thank the Botanic Garden of the University of Fribourg (Switzerland), as well as the Fondation Franklinia (Switzerland) for support during the field trip. Special thanks go to L. Fazan (University of Fribourg), A. Boratyński, K. Boratyńska, and J. Zieliński for their valuable comments on the preliminary version of the manuscript. The authors also like to thank Nguyen Van Ly, Nguyen The Huong, Trinh Van Thanh, Dao Thi Duong, Dao Cong Anh, Pham Quang Duong for theirs assistance in field trips.

\section{Conflict of interest}

The authors have no conflict of interest to declare.

\section{Author contributions}

Conceptualization: H.V.S., D.Q.T, and A.K.J.; Data curation: H.V.S, D.Q.T, D.T.B.N, A.K.J; Formal analysis: (equal); Investigation: H.V.S., D.Q.T, A.K.J.; Methodology: (equal); Supervision: H.V.S, A.K.J, G.K.; Writing - original draft: H.V.S, D.Q.T, D.T.B.N, P.T.T, D.T.T, S.B., F.R., Y.G.S.; Writing - review \& editing: H.V.S, D.Q.T, A.K.J, G.K. All authors have read and agreed to the published version of the manuscript.

\section{References}

APG III (2009) An update of the Angiosperm Phylogeny Group classification for the orders and families of flowering plants: APG III. Botanical Journal of Linnean Society 161:105-121. doi:10.1111/ j.1095-8339.2009.00996.x.

APG IV (2016) An update of the Angiosperm Phylogeny Group classification for the orders and families of flowering plants: APG IV. Botanical Journal of Linnean Society 181:1-20. doi:10.1111/ boj. 12385.

Ban NTE (2007) Vietnam Red Data Book, Part II: Plant. Science and Technology Publishing House, Hanoi.

Chan LM \& Huyen LT (2000) Forest plants of Vietnam. Agriculture Publishing house. Hanoi, Vietnam.

Department of Forest Protection (1997) Administrative penalties on violation of forest management, protection and management of forest's products. Agriculture Publishing House, Hanoi, Vietnam.

Dung VV (1996) Vietnam Forest Trees. Agriculture Publishing House. Hanoi, Vietnam.

Guo W, Chen J, Li J, Huang J, Wang Z \& Lim K-J (2020) Portal of Juglandaceae: A comprehensive platform for Juglandaceae study. Horticulture Research 7: 35. doi:10.1038/s41438-020-0256-x.

Hô PH (1992) Flore du Laos, du Cambodge et du Vietnam. Vol. 26. Muséum National d'Histoire Naturelle, Laboratoire de Phanérogamie, Paris, France.

Hô PH (2003) Flora of Vietnam, Vol. 2. Youth Publishing House. Ho Chi Minh, Vietnam.

Hoang VS, Baas P \& Keßler PJA (2008) Uses and Conservation of Plant Species in a National Park - A Case Study of Ben En. Vietnam Economic Botany 62: 574-593. doi:10.1007/s12231-008-9056-1.

Hoang VS, Baas P, Keßler PJA, Slik JWF, Ter Steege H \& Raes N (2011) Human and environmental influences on plant diversity and composition in Ben En national park, Vietnam. Journal of Tropical Forest Science 23, 328-337.

IUCN (2021) The IUCN red list of threatened species, version 2020-3. Retrieved from http://www. iucnredlist.org.

Kozlowski G, Bétrisey S \& Song YG (2018) Wingnuts (Pterocarya) and walnut family. Relict trees: Linking past, present and future. Fribourg: Natural History Museum Fribourg, p. 128.

Manchester SR (1989) Early history of the Juglandaceae. Plant Systematic and Evolution 162: 231250. doi:10.1007/BF00936919.

Manos PS\& Steele KP (1997) Phylogenetic analyses of "higher" Hamamelididae based on plastid 
sequence data. American Journal of Botany 84: 1407-1419. doi:10.2307/2446139.

Manos PS, Soltis PS, Soltis DE, Manchester SR, Oh S-H, Bell CD, Dilcher DL \& Stone DE (2007) Phylogeny of extant and fossil Juglandaceae inferred from the integration of molecular and morphological data sets. Systematic Biology 56: 412-430. doi:10.1080/10635150701408523.

Manos PS \& Stone DE (2001) Evolution, phylogeny, and systematics of the Juglandaceae. Annals of the Missouri Botanical Garden 88: 231-269. doi: $10.2307 / 2666226$.

Mercker H \& Vu PH (1997) Environmental policy and management in Viet Nam. Public Administration Promotion Centre, German Foundation for International Development, Berlin, Germany.

MOF (1991) Vietnam Forestry Sector Review Tropical Forestry Action Programame. Main Report.

Mu X-Y, Tong L, Sun M, Zhu Y-X, Wen J, Lin Q-W, Liu B (2020) Phylogeny and divergence time estimation of the walnut family (Juglandaceae) based on nuclear RAD-Seq and chloroplast genome data. Molecular Phylogenetics and Evolution 147: 106802. doi: 10.1016/j.ympev.2020.106802.

Nguyen NT (2007) Plant research methods. Hanoi National University Publishing House, Hanoi, Vietnam.

Pham HH 2003 Juglandaceae - Vietnamese plants, vol. 2. Youth Publishing House, Ho Chi Minh, Vietnam.

Schaarschmidt H (2014) Die Walnussgewächse. Juglandaceae. VerlagsKG Wolf., Magdeburg, Germany.

Simpson M (2010) Plant Systematics $2^{\text {nd }}$ Edition, Academic Press, San Diego State University, California, USA.
Song Y-G, Fragnière Y, Meng H-H, Li Y, Bétrisey S, Corrales A, Manchester S, Deng M, Jasińska AK, Văn Sâm H \& Kozlowski G (2020a) Global biogeographic synthesis and priority conservation regions of the relict tree family Juglandaceae. Journal of Biogeography 47:643-657. doi:10.1111/ jbi.13766.

Song Y-G, Li Y, Meng H-H, Fragnière Y, Ge B-J, Sakio $\mathrm{H}$, Yousefzadeh H, Bétrisey S \& Kozlowski G (2020b) Phylogeny, Taxonomy, and Biogeography of Pterocarya (Juglandaceae). Plants 9:1524. doi:10.3390/plants9111524.

Stone DE (1993) The families and genera of vascular plants Vol. 2.: Juglandaceae (ed. by K Kubitzki, JG Rohwer \& V Bittrich) Springer, Berlin, Germany, pp. 348-359.

Šlechtová V, Musilova Z, Tan HH, Kottelat M \& Bohlen J (2021) One northward, one southward: Contrasting biogeographical history in two benthic freshwater fish genera across Southeast Asia (Teleostei: Cobitoidea: Nemacheilus, Pangio), Molecular Phylogenetics and Evolution 161: 107139. doi:10.1016/j.ympev.2021.107139.

Tran H \& Nguyen BQ (1993) Vietnam Economic Forest Trees, Agricultural Publishing House, Hanoi, Vietnam.

Wu ZY \& Raven PH (eds.) (1999) Flora of China. Vol. 4 (Cycadaceae through Fagaceae). Science Press, Beijing, Missouri Botanical Garden Press, St. Louis, USA.

Zhang C-Y, Low SL, Song Y-G, Nurainas, Kozlowski G, Li L, Zhou S-S, Tan Y-H, Cao G-L, Zhou Z, Meng H-H \& Li J (2020) Shining a light on species delimitation in the tree genus Engelhardia Leschenault ex Blume (Juglandaceae). Molecular Phylogenetics and Evolution 152:106918. doi:10.1016/j.ympev.2020.106918. 